К.С. Смеляков ${ }^{1}$, А.С. Чуприна ${ }^{1}$, Д.Л. Сандркін ${ }^{1}$, Є.В. Вакулік ${ }^{1}$, Є.М. Дроб ${ }^{2}$

${ }^{1}$ Харківський національний університет радіоелектроніки, Харків

${ }^{2}$ Харківський національний університет Повітряних Сил ім. І. Кожедуба, Харків

\title{
РОЗРОБКА ІНВАРІАНТНОЇ МОДЕЛІ ЦИФРОВОГО ЗОБРАЖЕННЯ ДЛЯ ШВИДКОГО ПОШУКУ У СХОВИЩАХ ДАНИХ
}

У статті пропонується нова модель цифрового зображення, яка розробляється для можливості швидкого і стійкого пошуку зображень в сучасних великих архівах і сховищах даних. Головна особливість моделі полягає в тому, щзо вона є інваріантною до більшості найбільш поширених перетворень формату файлу зображення і самого зображення. Відносно перетворень афінної групи, градаційної корекції, підвищення різкості та інших змін яскравості і контрастності зображення. Інваріантність забезпечує стійкість застосування моделі в умовах перетворень зображення. Висока швидкість пошуку досягається за рахунок використання порівняно невеликого стандартного пошукового шаблону зображення.

Ключові слова: інваріантна модель, циифрове зображення, ивидкий пошук, сховище даних.

\section{Вступ}

Постановка проблеми. В даний час спостерігається стрімке зростання кількості і обсягу різноманітних сховищ цифрових зображень (фотографій): персональних архівів, корпоративних сховищ, фотобанків і сховищ інших типів. Разом з тим алгоритми і технології управління такими сховищами не завжди відповідають вимогам, що пред'являються по точності і швидкості роботи. Що істотно стримує ефективність розвитку і використання сучасних сховищ зображень.

Аналіз останніх досліджень і публікацій. Алгоритми управління сховищами зображень все більше використовують рішення в області комп'ютерного зору [1-3] і штучного інтелекту [4-6] для ефективного впровадження технологій пошуку [7-8]. Оскільки більшість процедур управління сховищем заснована на порівнянні та пошуку зображень [911]. У цьому відношенні ведуча роль відводиться сервісам, які шукають зображення по зображенню, порівнюючи властивості різних зображень в сховищі [12], а не за ключовими словами і / або метаданими [13]. Ефективність пошуку зображень в сховищах із застосуванням таких сервісів не забезпечується за кількома основними причинами. Головна 3 них пов'язана $з$ можливими перетвореннями зображень [9]. Протягом усього життєвого циклу зображення (і файли зображень) досить часто трансформуються користувачами i сервісами. Наприклад, файли часто піддають стисненню 3 втратою інформації [1]. Для самих зображень застосовують процедури градаційної корекції [14], підвищення різкості, фільтрації шуму, масштабування і багато інших [1; 15]. Для цілей поліпшення якості та приведення зображень до необхідного формату для подальшого використання. В результаті таких трансформацій змінюються властивості зображень. Крім цього спостерігаються проблеми з ефективністю розрізнення схожих зображень. Наявність цих двох основних причин (з урахуванням проблем Big Data i дублюванням зображень) призводить до неефективної роботи сервісів пошуку зображень [16-19]. Що в свою чергу обумовлює неефективність роботи систем управління сховищами зображень в цілому. В першу чергу, така ситуація викликана тим, що моделі цифрових зображень, які використовуються для пошуку всередині сховища не є інваріантними [20-22] до досить великої кількості поширених перетворень файлів і трансформацій самих зображень [9].

Мета статті - розробка інваріантної моделі цифрового зображення, щодо найбільш поширених перетворень файлу зображення і самого зображення, для швидкого пошуку у сховищах даних.

\section{Виклад основного матеріалу}

Одна 3 найбільш використовуваних інтегральних характеристик зображення - це його гістограма яскравості. Розглядаючи найпоширеніші трансформації зображення можна зробити висновок про те, що форма гістограми не змінюється. Може змінюватися іiі положення і локальні характеристики. Це справедливо для значущих перетворень афінної групи (поворот, дзеркальне відображення, масштабування), для більшості перетворень формату файлу, фотометричної корекції і ряду інших операцій. Ілюстрація цього спостереження наведена на рис. 1рис. 3 для найбільш використовуваних трансформацій. При цьому для афінної групи наводиться один результат - для повороту зображення, оскільки інші перетворення дають аналогічний результат. 


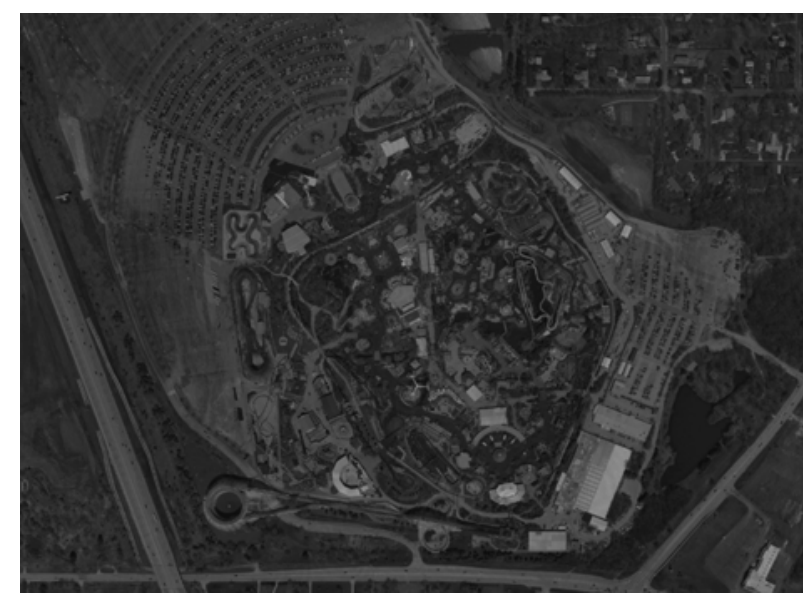

a

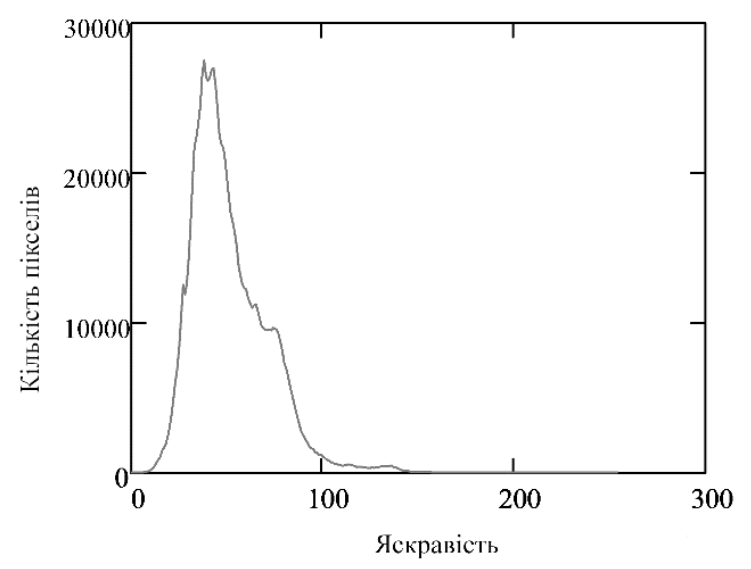

6

Рис. 1:

а - тестове зображення;

б - його гістограма яскравості

Джерело: розроблено авторами за даними [23].

Операції стиснення і розтягування незначно локально змінюють гістограму. Розтягування трохи iї згладжує (рис. 3 a), а стиснення, навпаки, трохи загострює локальні піки (рис. 3 б).

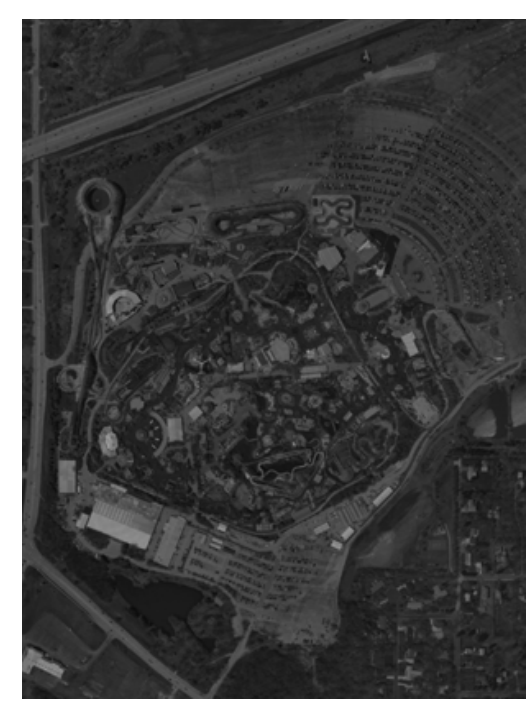

a

Рис. 2: a - початкове зображення, повернуте на $90^{\circ}$

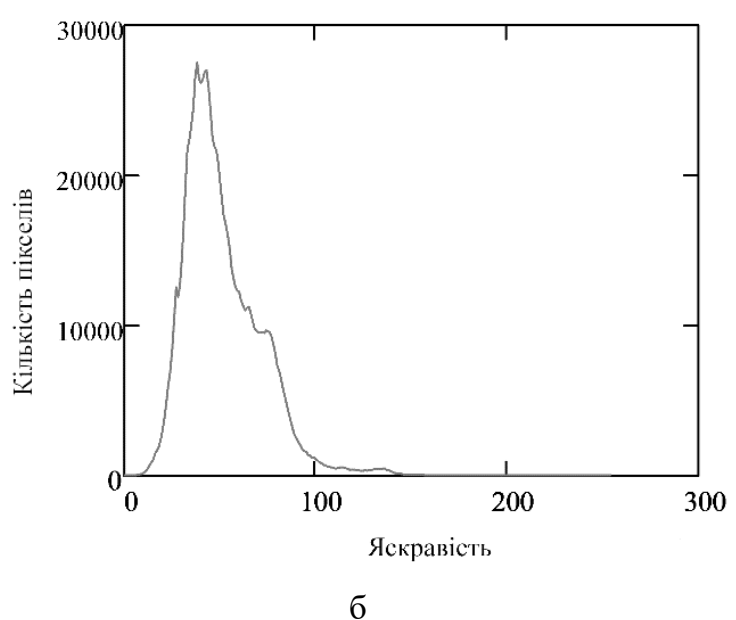

Рис. 2: б - його гістограма яскравості Джерело: розроблено авторами за даними [23].

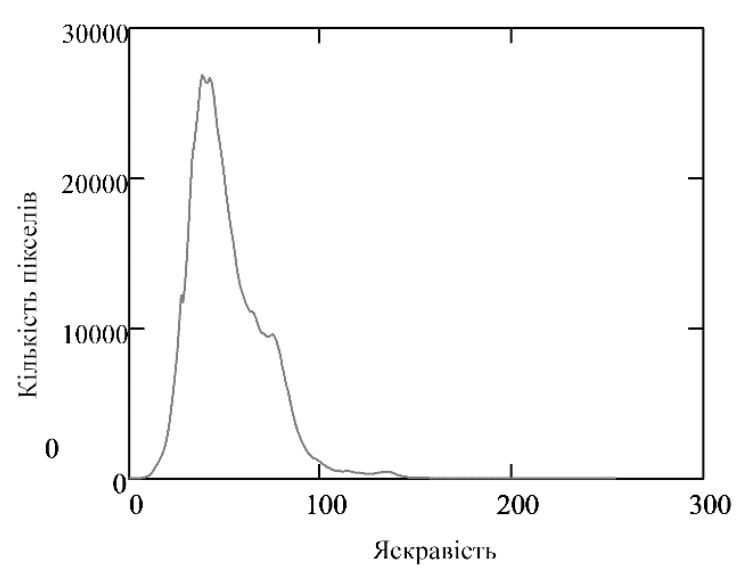

a

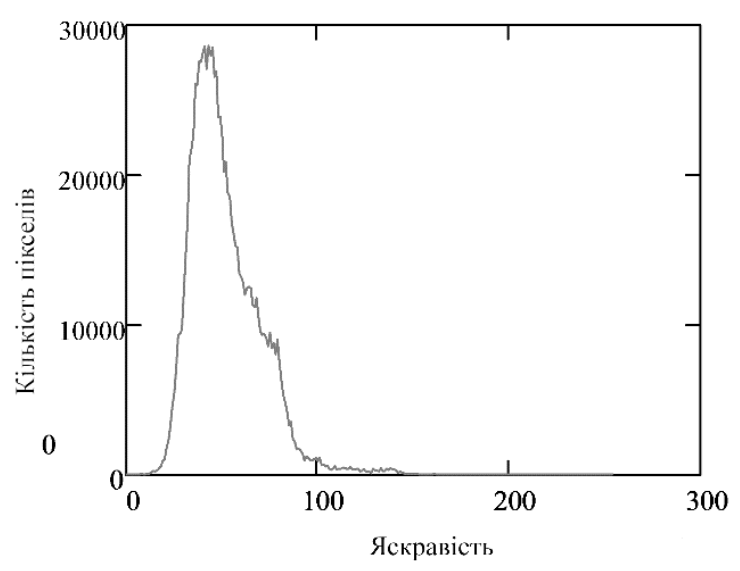

6

Рис. 3. Гістограми масштабованого зображення: а - розтягнутого в 4 рази;

б - стисненого в 4 рази, відповідно Джерело: розроблено авторами.

На рис. 3 самі зображення не наводяться, оскільки візуальні зміни яскравості і контрастності на цих зображеннях зовсім незначні. Гістограми геоме- 
трично перетворених зображень не змінюють свого положення по осі яскравості. Їх форма практично не змінюється. Можуть спостерігатися лише незначні локальні деформації.

Перейдемо до розгляду фотометричних змін зображення. Почнемо 3 простого. Збільшимо яскравість зображення на 100 одиниць (рис. 4).

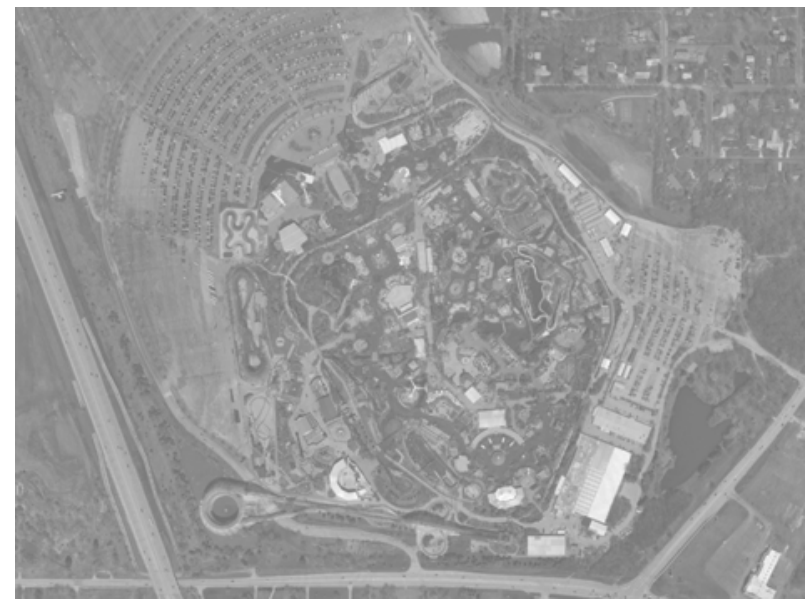

a

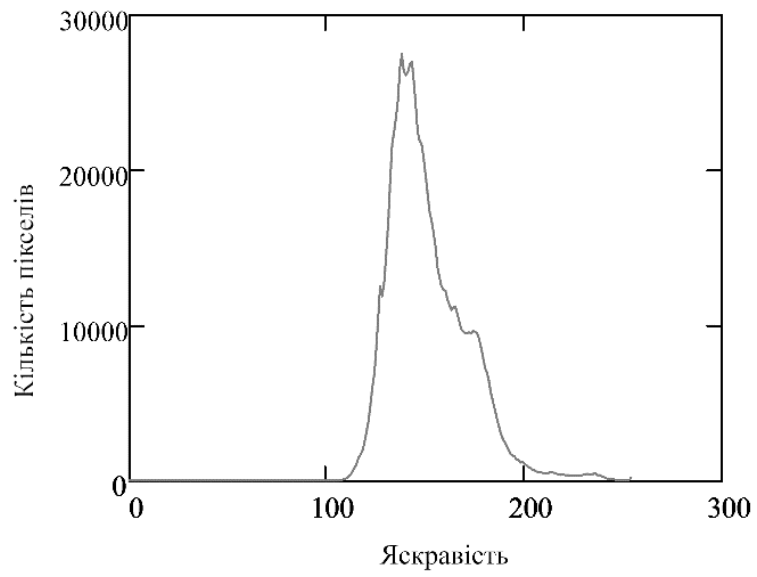

6

Рис. 4. Початкове зображення:

a - після збільшення його яскравості на 100 одиниць;

б - його гістограма

Джерело: розроблено авторами за даними [23].

Бачимо, що гістограма синхронно змістилася в бік більшої яскравості, при цьому форма гістограми збереглася.

На основі аналізу цих та ряду інших експериментів можна зробити висновок про те, що в більшості практично значимих трансформацій гістограма зображення взагалі не змінюється. У деяких випадках зміщується вздовж осі яскравості, або характеризується локальними деформаціями. Але форма гістограми все одно не змінюється.

У міру необхідності далі будуть розглянуті додаткові результати експериментів.

Зараз же зробимо головний висновок про те, що в цілому форма (структура) гістограми може виступати інваріантом. І цей факт доцільно використовувати для побудови моделі зображення.

Тим більше, що робота 3 гістограмою яскравості завжди дуже швидка.

\section{Побудова інваріантної моделі цифрового зображення}

Побудова моделі. Отже, в якості базової моделі для опису зображень будемо розглядати гістограму частостей яскравості. Побудова гістограми $h$ частостей $h_{i}, 0 \leq h_{i} \leq 1$, яскравості зображення: для кожної $i$ яскравості в діапазоні $[0, \ldots, 255]$ знаходимо іiі частоту $H_{i}$ i ділимо на $n: h_{i}=H_{i} / n$, $\sum_{i=0, \ldots, 255} h_{i}=1, \sum_{i=0, \ldots, 255} H_{i}=n$, де $n-$ це число пікселів зображення.

Зображення може піддаватися трансформаціям, наприклад, зміні рівнів яскравості. Наявність трансформацій може призводити до змін положення гістограми частостей $h$ (рис. 4 ).

У такій ситуації для можливості стабільно отримувати одні і ті ж межі гістограми частостей i, отже, адекватно порівнювати гістограми зображень необхідно усунути зміщення гістограми частостей i виділити іï ядро - фрагмент незмінної структури максимального розміру. Таким чином, забезпечується інваріантність моделі до перерахованих трансформацій.

Попередньо цього, необхідно враховувати той факт, що зображення може піддаватися викривленням і зашумленню. Це може призводити до появи нових яскравостей (як правило, з незначною частостей - $з$ амплітудою на рівні шуму), що буде знижувати стійкість всіх наступних етапів аналізу гістограми. Особливо - це призведе до неможливості / неадекватності ущільнення гістограми в аспекті усунення пустот.

Для усунення описаних негативних ефектів зробимо спочатку фільтрацію таких малозначущих / помилкових частостей.

Фільтрація. Для виконання фільтрації пропонується два альтернативних правила.

Правило 1 (адитивне). Обнуляємо частості гістограми менші порогу $t, \quad(0 \leq t<1)$. Таке правило може працювати не завжди адекватно. У деяких ситуаціях гістограма може пропорційно стискатися / розтягуватися. Разом 3 агрегуванням незначущих частостей. Якщо це можливо, в такій ситуації слід пропорційно змінювати поріг $t$. Але ми заздалегідь не знаємо про наявність таких перетворень. У такій ситуації краще використовувати мультиплікативне правило.

Правило 2 (мультиплікативне). Починаючи 3 найменшого позитивного значення (по зростанню), відзначаємо частості $h_{1} \leq h_{2} \leq \ldots \leq h_{k}$, сума яких не 
перевищує поріг $t, \quad(0 \leq t<1)$, а ця сума плюс наступна частість $h_{k+1}$ - більше порогу $t$. Усі зазначені частості обнуляються. Якщо серед решти значень $є$ частості рівні $h_{k}$, вони також обнуляються.

Яке б правило не було вибрано (правило вибирається на етапі навчання), проводимо нормування гістограми. Щоб сума частостей після фільтрації знову дорівнювала одиниці.

Нормування гістограми:

- знаходимо суму частостей $s=\sum h_{i}$ (перевіряємо, щоб $s \neq 0$, інакше генеруємо помилку);

- рахуємо коефіцієнт пропорційності $q=1 / s$;

- множимо частості $h_{i}$ на цей коефіцієнт $q$.

Номери частостей поки ще однозначно відповідають яскравостям пікселів.

Зауважимо, що апріорно нам не відомо, чи є спотворення / зашумлення зображення і наскільки вони проявлені. Але для стійкості подальшого аналізу необхідно врахувати можливість їх прояви i усунути.

Градаційна корекція, перетворення формату зображення, наприклад, трансформація в формат jpeg, можуть призводити до появи порожнеч усередині гістограми (через квантування / округлення яскравостей).

Ширина цих пустот може значно змінюватися як лінійним, так і нелінійним чином. Якщо глянути на таку гістограму, можна бачити смугастий спектр. У такій ситуації для збереження структури гістограми іiі доцільно ущільнити шляхом усунення пустот.

Ущзільнення. Знаходиться перша зліва ненульова частість; вона отримує номер (індекс) 1. Далі знаходиться наступна ненульова частість; вона отримує номер (індекс) 2. Таким чином, в циклі перенумеровуються всі значення гістограми 3 ненульовими частостями.

Після виконання операції ущільнення отримуємо ядро моделі (гістограми) без прив'язки до значень яскравості. Номери частостей вже не відповідають яскравості пікселів. Це ключовий момент роботи. Ядра гістограм вихідного і трансформованого зображень збігаються по положенню і по формі. Тому порівняння таких ядер дозволяє ефективно знаходити зображення в умовах трансформацій.

Чим більше стовпчиків у нашій гістограмі, тим більші локальні спотворення стовпчиків можуть вноситися варіаціями і перерозподілами яскравостей. Особливо при перерозподілі між суміжними значеннями (стовпчиками), коли одночасно в одному убуває, а в іншому - прибуває. Тому розгляд гістограми $h$ з шириною стовпчиків, що дорівнює одиниці не надто стабільний. Спотворення стовпчиків можна добре нівелювати за рахунок зростання ширини стовпчиків в результаті агрегації суміжних стовпчиків (інтервалів).

Агрегащія. Для виконання процедури агрегації пропонується такий алгоритм.

Крок 1. Спочатку знаходимо мінімальний $a$ i максимальний $b$ номера стовпчиків 3 ненульовою частістю (після ущільнення - це перший і останній стовпчики).

Крок 2. Визначаємо максимально допустиму кількість $m^{*}$ інтервалів - це максимальний ступінь двійки менший за $\Delta=(b-a+1)$, де $\delta=\Delta / m^{*}-$ ширина інтервалу (за замовчуванням розглядаємо інтервали рівної ширини).

Крім досить високої точності апроксимації гістограми, таке правило вибору числа інтервалів дозволяе в майбутньому “на льоту” формувати шаблони стандартного розміру кратного ступеня двійки, шляхом простого додавання суміжних стовпчиків, однак лише в бік зменшення числа стовпчиків.

Крок 3. Будуємо агреговану гістограму $g$ частостей на збільшених інтервалах так: частість на збільшеному інтервалі $i$ - це сума частостей інтервалів, які в нього потрапляють цілком плюс частки крайніх інтервалів, які він накриває частково. Межі укрупненого інтервалу на вхідній (ущільненій) гістограмі визначаємо так: $i=0, \ldots, m-1, \quad a_{i}=i \cdot \delta$, $b_{i}=(i+1) \cdot \delta$.

Частості цілих інтервалів між межами $a_{i}$ i $b_{i}$ просто додаємо, якщо вони є. Частки крайніх інтервалів визначаються так: частка лівого інтервалу: $d\left(a_{i}\right)=1-\left(a_{i} \% 1\right), \quad$ частка правого інтервалу $d\left(b_{i}\right)=b_{i} \% 1$, де \% - операція взяття дробової частини числа.

Пошуковий шаблон. Послідовність частостей агрегованої гістограми $g$ є матрицею-рядком, яку будемо називати пошуковим шаблоном. Його основні особливості:

1) порівняно невеликий розмір (як показують результати експериментів, найчастіше, довжина шаблону 32 або 64 елемента);

2) інваріантність до поширених перетворень файлу і самого зображення.

Що це нам дає? Можливість ефективного пошуку зображень на основі порівняння шаблонів, замість порівняння самих зображень.

Особливості побудови та використання такого шаблону є предметом подальших досліджень.

\section{Аналіз результатів експерименту}

На основі запропонованої моделі була розроблена відповідна інформаційна технологія і прототип пошукового сервісу.

На рис. 5-9 наведені типові результати пошуку зображень в сховищі. 


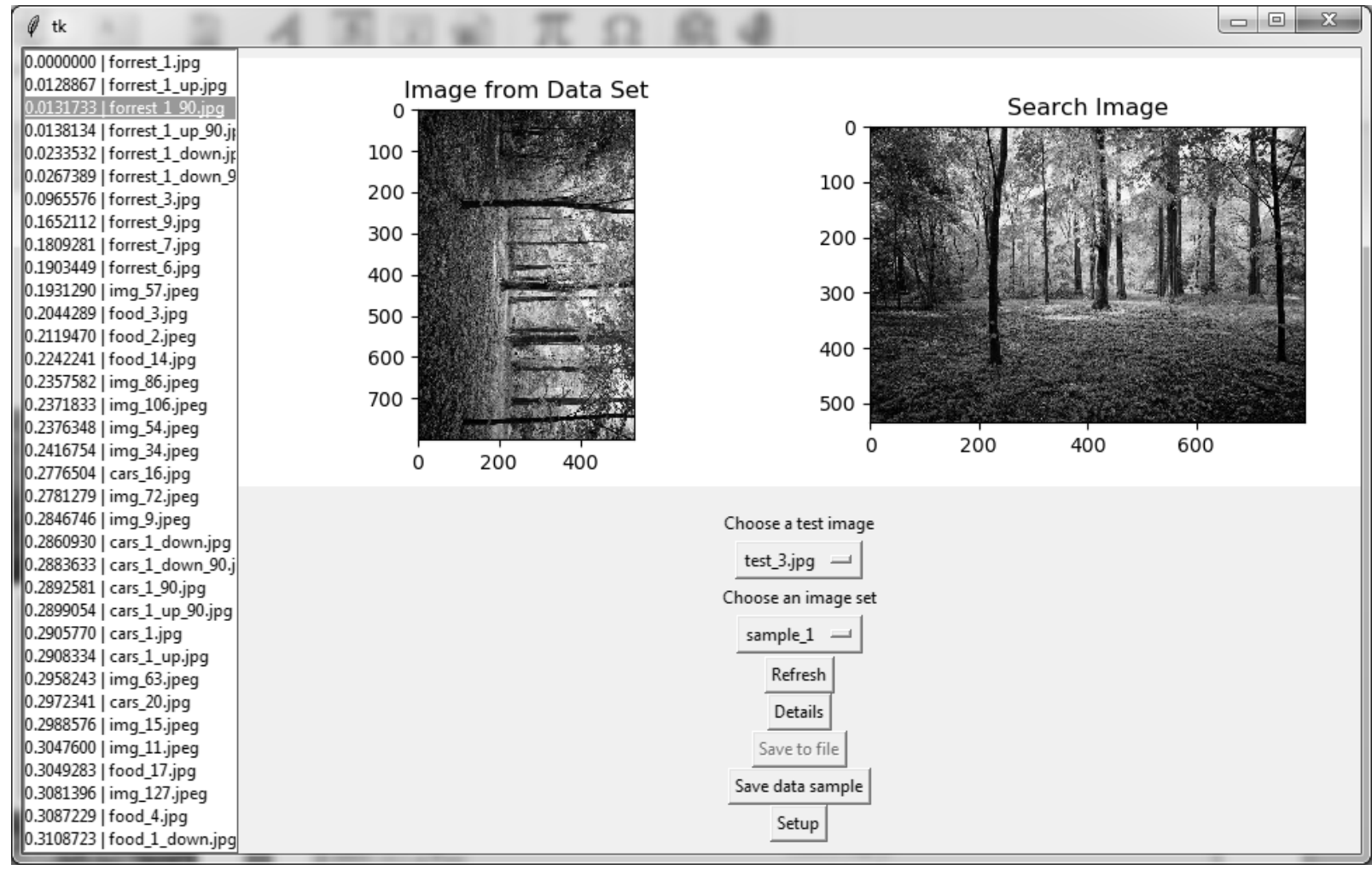

Рис. 5. Сортований список пошуку

Джерело: розроблено авторами.
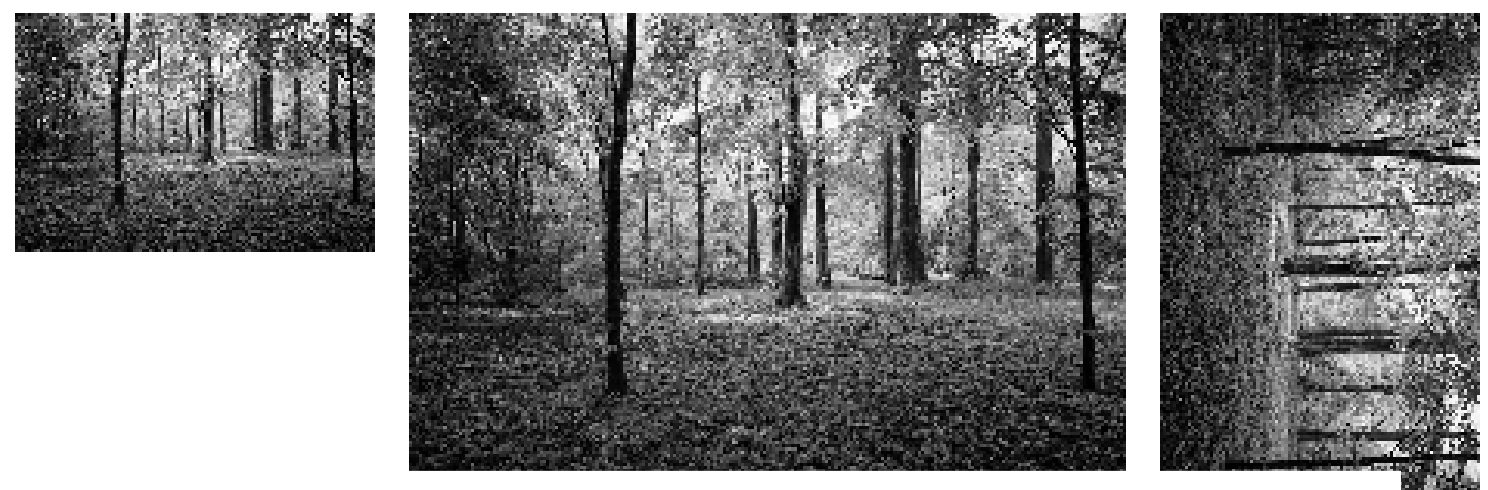

Рис. 6. Зображення ТОП-3 в порядку зростання дисперсії (зліва направо) Джерело: розроблено авторами.

Результат пошуку - це список зображень, сортовані за зростанням міри відмінності 3 оригіналом. В якості такої міри виступає оцінка дисперсії (відстань Хемімінга)

$$
s=\sum_{i=1}^{n}\left|x_{i}-y_{i}\right|,
$$

де різниця береться між відповідними елементами шаблонів $x, y$ порівнюваних зображень; попередньо шаблони приводяться до однієї довжини. Для перевірки інваріантності моделі до досліджуваних перетворенням зображень було проведено понад 1000 тестів на різних типах зображень. Були розглянуті близько 80 класів зображень (пейзажі, люди, архітектура, та ін.). Були розглянуті наступні основні перетворення: тонова корекція, підвищення різко- сті, поступова корекція, афінні перетворення (головним чином, масштабування, поворот і дзеркальне відображення) і перетворення формату файлу (в основному з bmp в jpeg). У всіх цих експериментах трансформовані зображення додавалися в сховище (об'ємом понад 100000 зображень) разом з оригіналом. Потім проводиться пошук оригіналу. У сховищі знаходилася велика кількість схожих / однотипних зображень (більше 1000 на клас). В результаті пошуку на першому місці з нульовою оцінкою дисперсії завжди знаходиться оригінальне (шукане) зображення. Відразу за ним йдуть спотворені оригінали. Після цього інші зображення зі сховища. Всі зображення відсортовані по зростанню дисперсії. В результаті проведених експериментів підтверджено, що запропонована модель $\epsilon$ інваріантною розгляну- 
тим перетворенням зображень. Модель дозволяє бражень. Типові результати пошукового забезпечувати стабільність пошуку в сховищах зо- експерименту наведені на рис. 7-9.

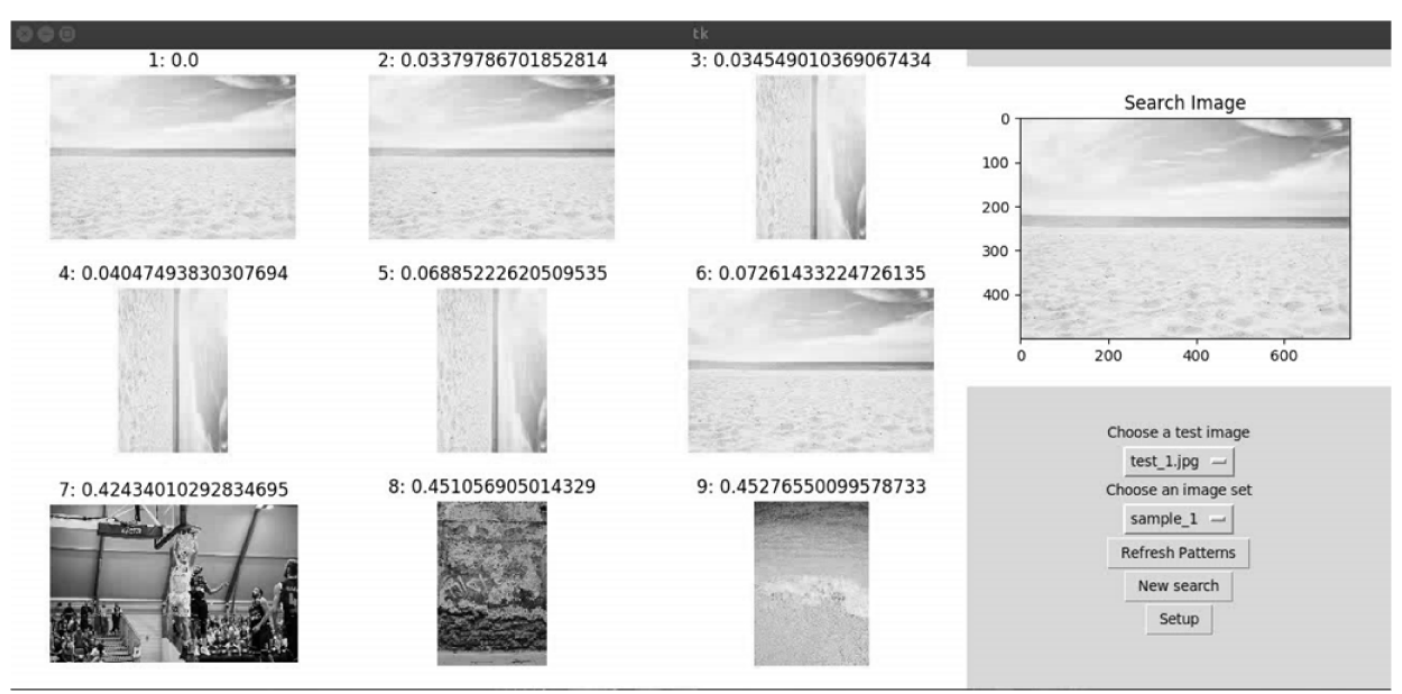

Рис. 7. Топ-9 результатів пошуку фото моря Джерело: розроблено авторами.

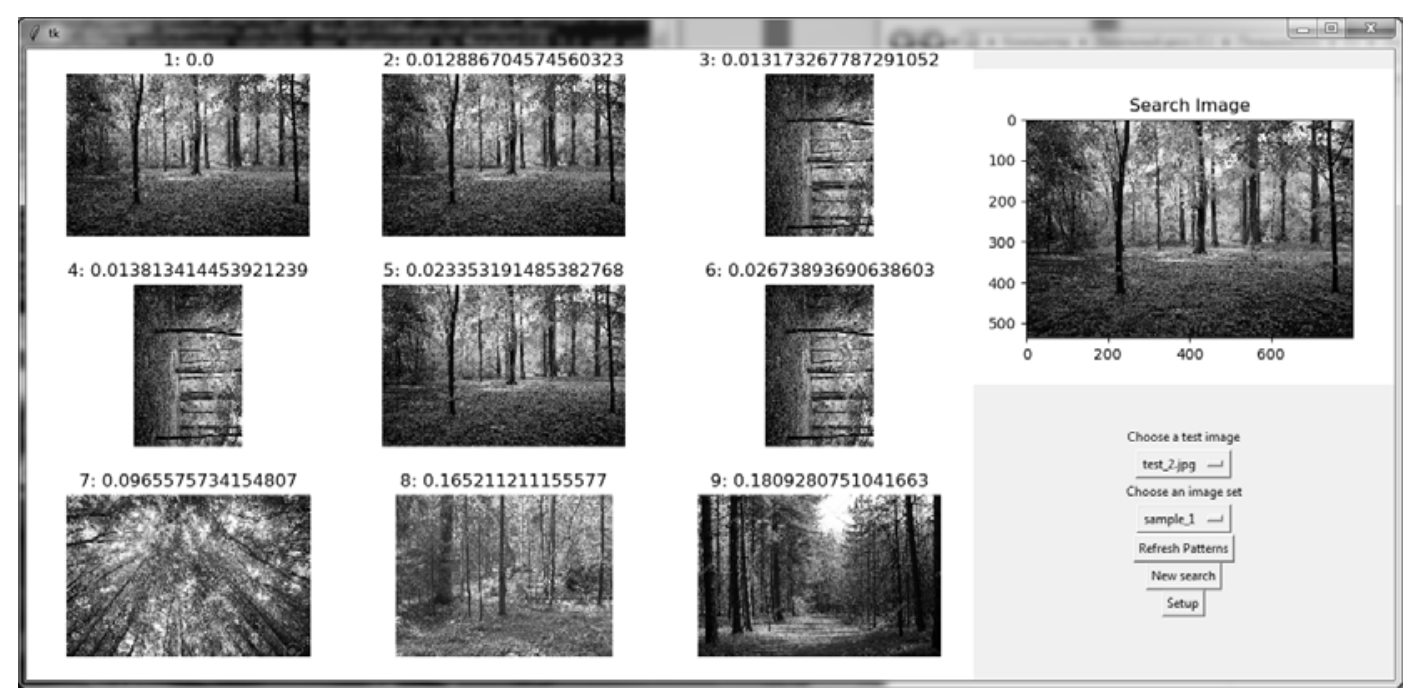

Рис. 8. Топ-9 результатів пошуку фото лісу Джерело: розроблено авторами.

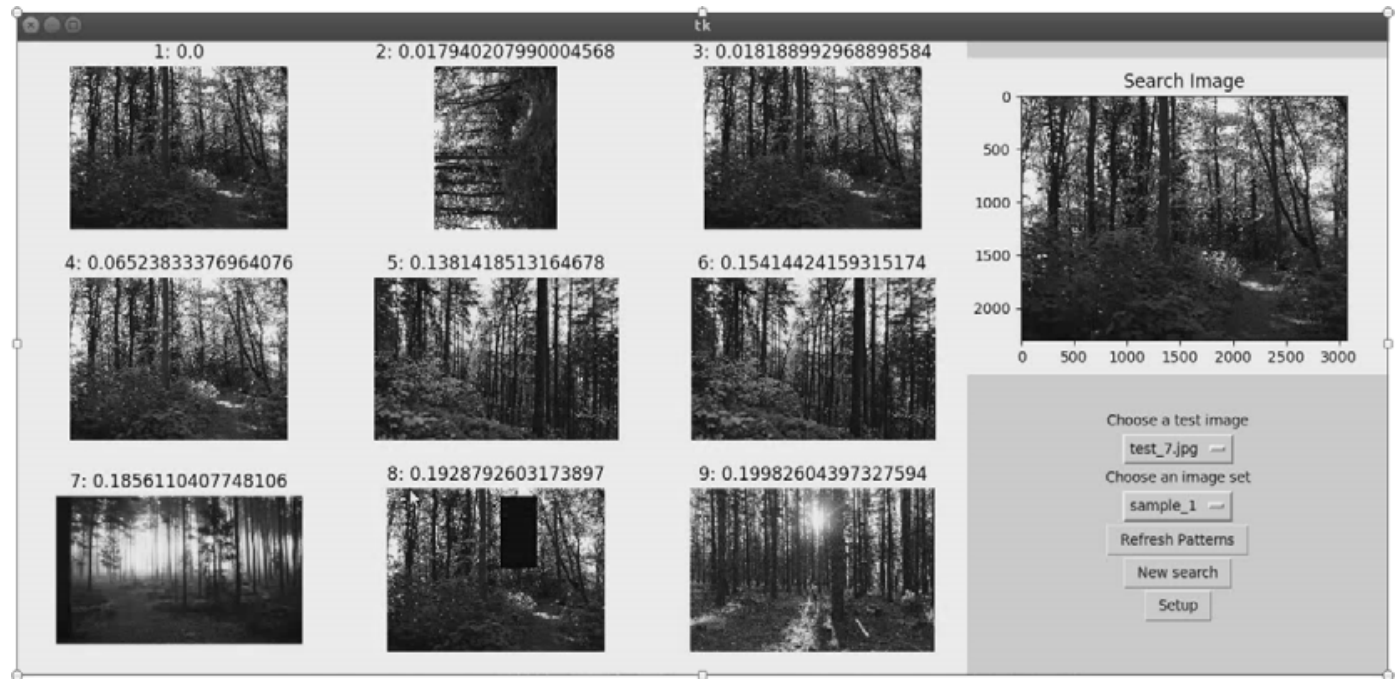

Рис. 9. Топ-9 результатів пошуку фото лісу Джерело: розроблено авторами. 
Крім того, в незначній мірі застосовувалися квантування рівнів яскравості, зашумлення і обрізка краю зображення. Модель показала стійкість і до цих впливів. Особливості оцінки швидкості пошуку 3 використанням шаблону є предметом подальших досліджень.

\section{Висновки}

На основі проведеного аналізу сучасного стану питання розроблена нова модель цифрового зображення, інваріантна більшості практично значимих перетворень файлу зображення і самого зображення. Відносно перетворень афінної групи, градаційної корекції, підвищення різкості та інших змін яскравості і контрастності зображення. У порівнянні 3 аналогами така інваріантність забезпечує стійкість застосування моделі в умовах перетворень зображення. Для іiі застосування для швидкого пошуку зображень у сховищах даних (особливо - великих даних). Це було доведено на практиці, за рахунок проведення численних пошукових експериментів. Які підтвердили теоретичні припущення і викладки.

\section{Список літератури}

1. Gonzalez R.C. Digital Image Processing / R.C. Gonzalez, R.E. Woods. - Pearson: Prentice Hall, 2018. - 1168 p.

2. Шапиро Л. Компьютерное зрение / Л. Шапиро, Дж. Стокман. - М.: БИНОМ, 2006. - 752 с.

3. Forsyth D.A. Computer Vision: A Modern Approach, 2nd ed. / D.A. Forsyth, J. Ponce. - London: Pearson Education Limited, 2015. - $792 \mathrm{p}$.

4. Goodfellow I. Deep Learning / I. Goodfellow, Y. Bengio, A. Courville. - Cambridge: MIT Press, 2016. - 787 p.

5. Norvig P. Artificial Intelligence: A Modern Approach / P. Norvig, S. Russell. - London: Pearson Education Limited, 2016. $-1152 \mathrm{p}$.

6. Deng L. Deep Learning Methods and Applications / L. Deng, Y. Dong // Foundations and Trends in Signal Processing. - 2013. - No. 3(7). - P. 197-387.

7. Corke P. Robotics, vision and control / P. Corke. - Berlin: Springer, 2017. - 693 p.

8. Яне Б. Цифровая обработка изображений / Б. Яне. - М.: Техносфера, 2007. - 584 с.

9. Search by Image. New Search Engine Service Model / K. Smelyakov, I. Ruban, D. Sandrkin, V. Martovytskyi, Y. Romanenkov // 5th International Conference Problems of Infocommunications. - Kharkiv, October 2018. - P. 181-186.

10. Network technology for transmission of visual information / S. Bielievtsov, I. Ruban, K. Smelyakov, D. Sumtsov // Selected Papers of the XVIII International Scientific and Practical Conference on Information Technologies and Security. Kharkiv, December 2018. - P. 160-175.

11. Smelyakov K. Adaptive Edge Detection Models and Algorithms / K. Smelyakov, S. Smelyakov, A. Chupryna // Springer. - 2020. - № 876. - P. 1-51.

12. Офіційний сайт SAP.COM. Image-Based Buying. - Режим доступу: https://help.sap.com/viewer.

13. Офіційний сайт PYIMAGESEARCH.COM. The 3 Types of Image Search Engines. - Режим доступу: https://www.pyimagesearch.com/2014/01/15/the-3-types-of-image-search-engines-search-by-meta-data-search-by-example-andhybrid/.

14. Gradational Correction Models Efficiency Analysis of Low-Light Digital Image / K. Smelyakov, A. Chupryna, M. Hvozdiev, D. Sandrkin // Conference of Electrical, Electronic and Information Sciences. - Vilnius, 25-25 April 2019. - P. 1-6.

15. Sonka M. Image processing, analysis and machine vision / M. Sonka. - Minnesota: Cole Publishing Company, 1999. $770 \mathrm{p}$.

16. Magda E.F. Image search algorithms / E.F. Magda, Ș. Cosmin, L.A. Ioan // 7th International Conference on Electronics, Computers and Artificial Intelligence. - Bucharest, 25-27 June 2015. - P. 35-40.

17. Image Search Algorithm in Local Data Base / O.A. Bodrov, A.S. Tarasov, V.Y. Tarasova, I.V. Bodrova // 8th Mediterranean Conference on Embedded Computing. - Budva, 10-14 June 2019. - P. 1-3.

18. Reverse Image Search for the Fashion Industry Using Convolutional Neural Networks / K.F. Mawoneke, X. Luo, Y. Shi, K. Kita // 5th International Conference on Signal and Image Processing. - Nanking, 23-25 October 2020. - P. $483-489$.

19. Jain S. Image based search engine using deep learning / S. Jain, J. Dhar // Tenth International Conference on Contemporary Computing. - Noida, 10-12 August 2017. - P. 1-7.

20. Dimension Invariant Model for Human Head Detection / S.D. Khan, H. Ullah, M. Ullah, F.A. Cheikh, A. Beghdadi // 8th European Workshop on Visual Information Processing. - Rome, 28-31 October 2019. - P. 99-104.

21. Maw H.M. Face Recognition based on Illumination Invariant Techniques Model / H.M. Maw, S.M. Thu, M.T. Mon // International Conference on Advanced Information Technologies. - Yangon, 6-7 November, 2019. - P. 120-125.

22. Si J. Age-invariant face recognition using a feature progressing model / J. Si, W. Li // 3rd IAPR Asian Conference on Pattern Recognition. - Kuala Lumpur, 6-7 November 2015. - P. 775-780.

23. Офіційний сайт GEOGRAPHYOFRUSSIA.COM. Aerial photography. - Режим доступу: https:// geographyofrussia.com/wp-content/uploads/2009/03/00.jpg. 
Відомості про авторів:

\section{Смеляков Кирило Сергійович}

доктор технічних наук професор

професор кафедри Харківського національного

університету радіоелектроніки,

Харків, Україна

https://orcid.org/0000-0001-9938-5489

\section{Чуприна Анастасія Сергіївна}

кандидат технічних наук доцент кафедри

Харківського національного

університету радіоелектроніки,

Харків, Україна

https://orcid.org/0000-0003-0394-9900

Сандркін Денис Леонідович

аспірант Харківського національного

університету радіоелектроніки,

Харків, Україна

https://orcid.org/0000-0002-3542-5194

\section{Вакулік Свген Вікторович}

магістр Харківського національного

університету радіоелектроніки,

Харків, Україна

https://orcid.org/0000-0002-4940-0529

\section{Дроб Євген Маркович}

кандидат технічних наук

доцент кафедри Інституту цивільної авіації

Харківського національного університету

Повітряних Сил ім. І. Кожедуба

Харків, Україна

http://orcid.org/ 0000-0002-2015-220X

\section{Information about the authors:}

Kyrylo Smelyakov

Doctor of Technical Sciences Professor

Professor of Department

of Kharkiv National University of Radio Electronics, Kharkiv, Ukraine

https://orcid.org/0000-0001-9938-5489

\section{Anastasiya Chupryna \\ $\mathrm{PhD}$}

Senior Lecturer of Department

of Kharkiv National University of Radio Electronics, Kharkiv, Ukraine

https://orcid.org/0000-0003-0394-9900

Denys Sandrkin

Doctoral Student

of Kharkiv National University of Radio Electronics, Kharkiv, Ukraine

https://orcid.org/0000-0002-3542-5194

\section{Eugen Vakulik}

Master

of Kharkiv National University of Radio Electronics, Kharkiv, Ukraine

https://orcid.org/0000-0002-4940-0529

\section{Yevhen Drob}

$\mathrm{PhD}$ in Technical Sciences

Senior Lecturer of Department

of Civil Aviation Institute of Ivan Kozhedub Kharkiv

National Air Force University,

Kharkiv, Ukraine,

http://orcid.org/0000-0002-2015-220X

\section{РАЗРАБОТКА ИНВАРИАНТНОЙ МОДЕЛИ ЦИФРОВОГО ИЗОБРАЖЕНИЯ ДЛЯ БЫСТРОГО ПОИСКА В ХРАНИЛИЩАХ ДАННЫХ}

К.С. Смеляков, А.С. Чуприна, Д.Л. Сандркин, Е.В. Вакулик, Е.М. Дроб

В статье предлагается новая модель цифрового изображения, которая разрабатывается для возможности быстрого и устойчивого поиска изображений в современных больших архивах и хранилищах данных. Главная особенность модели состоит в том, что она является инвариантной большинству наиболее распространенных преобразований формата файла изображения и самого изображения. В отношении преобразований аффинной группы, градационной коррекиии, повышения резкости и иных изменений яркости и контрастности изображения. Инвариантность обеспечивает устойчивость применения модели в условиях преобразований изображения. Высокая скорость поиска достигается за счет использования сравнительно небольшого стандартного поискового шаблона изображения.

Ключевые слова: инвариантная модель, цифровое изображение, быстрый поиск, хранилище данных.

\section{DEVELOPMENT OF INVARIANT DIGITAL IMAGE MODEL FOR QUICK SEARCH IN DATA STORAGES}

K. Smelyakov, A. Chupryna, D. Sandrkin, E. Vakulik, Ye. Drob

The article proposes a new digital image model, which is specially designed to be able to search for images quickly and consistently in modern large archives and data warehouses. And also, in the Internet. The main feature of the proposed model is that it is invariant to most of the most common transformations of the image file format and the image itself. The paper deals with such transformations as image scaling, image rotation, image mirroring, tone correction, gradation correction, sharpening and several other transformations. The development of an invariant model is necessary to ensure the stability of the application of the model under the conditions of image transformations. So that these transformations do not affect the received search results in any way. So that we are guaranteed to find the image, no matter how it is transformed. The paper also describes the results of the experiment, proving the stability of the search in terms of image transformations. The essence of the experiment is as follows. An image is fetched from the repository. This image is transformed in several ways. Then the original image and all its distorted copies are placed in storage. In addition to a wide variety of images, including a large number of images similar to the original. The images in the repository are then ordered in ascending order of difference from the original based on a comparison of their search patterns. As a result of the experiments, the order of the images in the final sorted list is adequate. The original is always output first. Its transformed copies always follow immediately after it. Then the rest of the images. High search speed is achieved by using a relatively small standard image search template. An analysis of the computational efficiency of using such a template is planned to be given in the next work.

Keywords: invariant model, digital image, fast search, data warehouse. 